\title{
Gompertz law and aging as exclusion effects
}

\section{Anund Hallén}

Published online: 15 September 2009

(C) Springer Science+Business Media B.V. 2009

Erratum to: Biogerontology (2007) 8:595-603 DOI 10.1007/s10522-007-9092-8, 10.1007/s10522-007-9087-5

Article 10.1007/s10522-007-9087-5 published in Biogerontology Volume 8, Number 5 (October 2007) was published twice as article 10.1007/s10522-0079092-8.

In brief, article 10.1007/s10522-007-9092-8 is a duplicate of article 10.1007/s10522-007-9087-5.

The online version of the original article can be found under doi:10.1007/s10522-007-9092-8, 10.1007/s10522-007-9087-5.

\footnotetext{
A. Hallén $(\bowtie)$

Department of Medical Biochemistry and Microbiology, University of Uppsala, Biomedical Center, P.O. Box 582,

75123 Uppsala, Sweden

e-mail: anund.hallen@swipnet.se
} 